\title{
Dynamics of soil organic carbon and dissolved organic carbon in Robina pseudoacacia forests
}

\author{
H. $\operatorname{Lv}^{1,3}$ and Z. Liang ${ }^{1,2^{*}}$ \\ ${ }^{1}$ Institute of Soil and Water Conservation, Chinese Academy of Science and Ministry of Water Resources, \\ Yangling, Shaanxi 712100, P.R. China. ${ }^{2}$ College of Life Science, Northwest A\&F University, Yangling, Shaanxi \\ 712100, P.R. China. ${ }^{3}$ Weinan Teachers University, Weinan, Shaanxi 714000, P.R. China. ${ }^{*}$ Corresponding author: \\ liangzs@ms.iswc.ac.cn
}

\begin{abstract}
We investigated the variation patterns of organic carbon in soil and soil solution of four selected Robinia pseudoacacia forests aged 10a, 25a, 31a, and 35a, as well as a contrastive tillage site in a similar topography condition in Loess Plateau, China. The purpose was to explore the dynamics of soil organic carbon (SOC) and dissolved organic carbon (DOC) in R. pseudoacacia forests. On average depths of 20, 40 , and $60 \mathrm{~cm}$, SOC, active organic carbon (AOC), and DOC gradually increase with increased forest age. After forest restoration, the AOC/SOC ratio and resistant organic carbon/SOC ratio increase, whereas the slow organic carbon/SOC ratio decreases. The soil solutions in the subsoil layer have low DOC:DON ratio and high UV absorption at $280 \mathrm{~nm}$. At 40 and $60 \mathrm{~cm}$, the depth distribution is indicated as special low values for DOC concentration in the C99 site (10a site), as well as for soil water content, SOC, and AOC in the $25 \mathrm{a}$ forest site. Our results provide evidence that during forest restoration, SOC does not consistently increase linearly. The change points of different SOC proportions and DOC concentrations at various depths are not same, i.e., asynchronous changes exist.
\end{abstract}

Keywords: depth distribution, soil organic carbon dynamics, active organic carbon (AOC), UV absorption at $280 \mathrm{~nm}$. 


\section{Introduction}

Soils have the potential for carbon (C) release or sequestration. Hence, soil organic carbon (SOC) is related to atmospheric $\mathrm{CO}_{2}$ levels, which can be affected by vegetation cover and land management (Lal, 2004). When land is converted from one cover type to another, research on SOC dynamics is valuable in improving our comprehension and increasing our predictive capability over both short- and long-term scales (Post and Kwon, 2000). Land cover changes affect litters, plant root, soil fauna, soil microorganisms, and soil condition, which can drastically alter the soil carbon stock. Generally, the transformation of cultivated soil to forest ecosystem can realize additional soil carbon sequestering. The concomitant development of soil carbon and vegetation in primary and secondary chronosequences was documented by Bush et al. (2008), among others. SOC increases by up to $52 \%$ after a change from crop to secondary forest (Guo et al., 2002). Forests with nitrogen-fixing trees may also allocate a higher fraction of their net primary production to soil (e.g., Bush, 2008; Kiser et al., 2009). However, the results of soil carbon stock change in forest chronosequence are likely to be different. The increasing trend of soil carbon is not always represented in the entire forest chronosequence or at each depth. Zhou et al. (2006) found that pioneer and transition forests had limited effects on SOC accumulation even if the aboveground biomass rapidly accumulates and reaches a high level. In the hilly Loess Plateau of China, Wang et al. (2010) indicated that SOC contents are significant for different land covers in a semi-arid climate only at $5 \mathrm{~cm}$ soil surface depth. Cropland transformation to immature woodland has no significant effect on SOC.

SOC is greatly susceptible to environment change, especially to vegetation cover changes (Wang et al., 2011). Large amounts of worldwide soil carbon data need to be analyzed to explore highly inherent natural variability in worldwide soils and carbon loss rules under different land cover types and change trajectories (Lal, 2009). The mechanism of SOC dynamics in forest chronosequences needs to be determined.

In forest, grass, and shrub vegetation restoration, DOC leaching plays an important role in SOC at different depths, which is a crucial function in the belowground carbon cycle. The largest increase in the flux of dissolved organic matter (DOM) occurs when percolating water passes through the forest floor (Michalzik et al., 2001). DOM leaching from organic layers to mineral soils and DOM sorption onto mineral surfaces are very likely to be important mechanisms in stabilizing soil organic matter (Kalbitz and Kaiser, 2008). Therefore, both SOC and DOC should be calculated and measured in predicting ecosystem response to global change, especially for depth distribution.

The Loess Plateau in China covers approximately $58 \times 10^{4} \mathrm{~km}^{2}$. In the $1970 \mathrm{~s}$, the Chinese government began an extensive tree plantation. Since then, the Zhifanggou drainage area of the Ansai country of Shaanxi province has undergone remarkable land use change. The conversion of degraded lands into forests and grasslands was essentially promoted by the state-funded project, Grain-for-Green, in 1999. The eco-environment was improved under government regulations of reforestation/planting grass (Fu et al., 2010). The restored forest species included Platycladus orientalis, Quercus variabilis, Robinia pseudoacacia, and Pinus tabulaeformis, among others. In the Zhifanggou drainage basin, one of the main restored species, $R$. pseudoacacia, was planted extensively as a kind of pioneer forest plant because of its high adaptability. Restored R. pseudoacacia forests of different ages were mixed with one another at patch scales in the Zhifanggou drainage basin, enabling the selection 
of suitable sites in a small field. The present study used a special comparison method to (1) estimate SOC dynamics in a period of 35 years for $R$. pseudoacacia forest restoration in a similar topographic condition, (2) investigate the mechanism of SOC and DOC dynamics during the development of forest vegetation, and (3) explore the depth distribution of SOC and its potential change mechanism in forest restoration.

\section{Materials and Methods}

\subsection{Field site and sampling regime}

The study area is the Zhifanggou drainage basin $\left(109^{\circ} 13^{\prime} 46^{\prime \prime}-109^{\circ} 16^{\prime} 03^{\prime \prime}\right.$ E , 36 $46^{\circ} 42^{\prime \prime}-36^{\circ} 46^{\prime} 28^{\prime \prime}$
$\mathrm{N})$, located in the middle part of the Loess plateau in northern Shaanxi Province, P. R. China (Figure 1). Due to significant topographic variations within the Loess hills and gully landforms, only a small area of $275 \mathrm{~m} \times 212.5 \mathrm{~m}$ is covered to ensure that all selected sites had similar topographic conditions. Four $R$. pseudoacacia forest sites and one tillage site were selected (Table 1). The region mainly has a semi-arid climate of warm temperate zone, with an annual accumulative radiation of $493 \mathrm{~kJ} \mathrm{~cm}^{-2}$. The average annual temperature is $8.8{ }^{\circ} \mathrm{C}$ and the mean annual precipitation is $549.1 \mathrm{~mm}$. The soil in the study area is fine silt to silt in texture and weakly resistant to erosion.

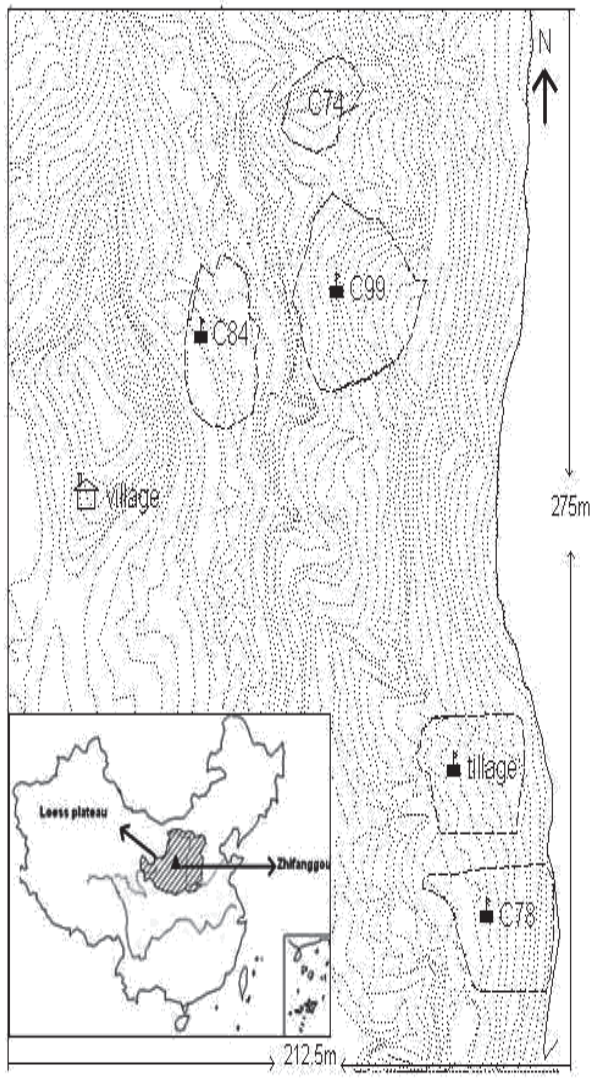

Figure 1. Location of the study sites with a $2 \mathrm{~m}$ contour lines. 
Table 1. Summary of land-use history, geographic condition, vegetation and plantling details of five study sites.

\begin{tabular}{cccccccccc}
\hline $\begin{array}{c}\text { Sample } \\
\text { sites }\end{array}$ & $\begin{array}{c}\text { Stand age } \\
(\mathbf{y} \text { (ears) }\end{array}$ & $\begin{array}{c}\text { Acreage } \\
\left(\mathbf{m}^{2}\right)\end{array}$ & $\begin{array}{c}\text { Old } \\
\text { land use }\end{array}$ & Aspect & $\begin{array}{c}\text { Slope } \\
\left({ }^{\circ}\right)\end{array}$ & $\begin{array}{c}\text { Crown } \\
\text { density }\end{array}$ & $\begin{array}{c}\text { Total litters } \\
\left(\mathbf{g ~ m}^{-2}\right)\end{array}$ & $\begin{array}{c}\text { Trunk } \\
\text { diameter } \\
(\mathbf{c m})\end{array}$ & $\begin{array}{c}\text { Tree } \\
\text { height } \\
(\mathbf{m})\end{array}$ \\
\hline Tillage & $\infty$ & 1220 & - & W & 20.2 & - & - & - & - \\
C99 & 10 & 1581 & Tillage & SWW & 27.3 & $0.9-0.95$ & 348.3 & 11.4 & $11-12$ \\
C84 & 25 & 913 & Tillage & SWW & 21.4 & $0.5-0.6$ & 262.4 & 12.8 & $15-20$ \\
C78 & 31 & 1344 & Tillage & SWW & 21.4 & $0.75-0.8$ & 362.9 & 23.8 & $15-20$ \\
C74 & 35 & 486 & Tillage & SWW & 18.3 & $0.85-0.9$ & 298.6 & 30.1 & $>20$ \\
\hline
\end{tabular}

In 1973, the Zhifanggou basin was selected as an experimental site by the Key Technologies Research and Development Program on the comprehensive management of the Loess Plateau. Partial farmlands were reverted into forests and grasslands in batches. Four kinds of $R$. pseudoacacia forests were respectively planted in 1999 (10a or C99), 1984 (25a or C84), 1978 (31a or C78), and 1974 (35a or C74). The forests herbs include Arundinella hirta, Roegneria kamoji, Viola yedoensis, Aneurolepidium dasystachys, Artemisia japonica, Carex rigescens, Agropyron cristatum, etc. The tillage study site has existed since 1974 and is less affected by chemical fertilizer. When cropland in this area was gradually restored to forest, grassland, or shrub, the tillage site was kept but the corns, soybean, and millet were rotated. Four forest sites and the tillage site locate in $200-500 \mathrm{~m}$ east to Shiyaoxian village, where all restored forest fields were distributed to villagers in order to manage effectively. According to old villager's introduction, in history the study area had been utilized as farmland by serious food demand until 1973 .

An average of nine sections was selected in each study site. Samples from depths of $20 \pm 2,40 \pm 2$, and $60 \pm 2 \mathrm{~cm}$ were obtained using a soil drill and evenly mixed with three horizontal samples, respectively. We enclosed these samples in a plastic bag and stored them in the laboratory at $2{ }^{\circ} \mathrm{C}$. Three $100 \mathrm{~cm}$-deep holes were randomly selected and dug in each study site. Samples were collected from depths of 5-10, 30-35, 60-65, and 90-95 cm, and stored in $50 \mathrm{~mL}$ aluminum boxes to determine the soil water content and soil bulk density.

\subsection{Sampling and analysis}

The moisture samples in aluminum boxes were weighed wet, dried at $105^{\circ} \mathrm{C}$ for $48 \mathrm{~h}$, and weighed again to determine the bulk density and gravimetric soil water content. After air drying soil samples for 3 days, litters were carefully picked out, crushed to pass through a 1 mm sieve, and stored at $2{ }^{\circ} \mathrm{C}$ until analysis.

In 1989, Parton (1989) divided SOC into active (AOC), slow (LOC), and resistant C pool (ROC) based on the mean residence times. In the present study, SOC was determined using the routine potassium dichromate oxidation-outer heating method. The 333 $\mathrm{mM} \mathrm{KMnO}_{4}$ chemical oxidation method was used for AOC determination (Conteh et al., 1997). ROC was determined by the acid hydrolysis method (Collins et al., 2000). About $1 \mathrm{~g}$ of soil samples were hydrolyzed with $20 \mathrm{~mL}$ of $6 \mathrm{M} \mathrm{HCl}$ in sealed Pyrex tubes at $105^{\circ} \mathrm{C}$ for $18 \mathrm{~h}$. The hydrolysate was then discarded. 
After washing unhydrolyzed residues with deionized water by repeated centrifugations and decantations, the samples were transferred to pre-weighed vials and dried at $60^{\circ} \mathrm{C}$ to constant weight. Subsequently, SOC was analyzed. LOC was calculated by difference between SOC and ROC (LOC $=\mathrm{SOC}-\mathrm{ROC})$.

DOM was collected using a soil-to-solution (distilled water) ratio of $1: 5$, shaken for $1 \mathrm{~h}$, and centrifuged (2000 rpm for $10 \mathrm{~min}$ ). The solution was collected, filtered through $0.45 \mu \mathrm{m}$ cellulose acetate filters, and stored in a frozen state until analysis. DOC was determined with a TOC Analyzer (Phoenix 8000). Total nitrogen (TN) in the solution was determined using a photometer after persulfate digestion. Inorganic nitrogen was determined using a continuous flow analyzer (AA3). Dissolved organic nitrogen (DON) was determined by the difference between $\mathrm{TN}$ and dissolved inorganic nitrogen (DIN), i.e., $\mathrm{DON}=\mathrm{TN}$ - DIN. The UV absorbance at $280 \mathrm{~nm}$ was measured (adjustive solution of $10 \mathrm{mg} \mathrm{L}^{-1} \mathrm{DOC}$, calculated by dividing measured UV absorption at $280 \mathrm{~nm}$ ) to estimate aromaticity (Zsolnay et al., 1999). All samples were determined with three replicates.

\subsection{Data handling and statistics}

All figures and most data were made using Excel 2003 and SPSS 16.0 software. One-way ANOVA was used to examine the effects of the vegetation restoration type on the concentrations and stocks of soil carbon. If significant effects were observed by ANOVA, a least significant difference [LSD (0.05)] test was used.

\section{Results}

\subsection{Soil water content and bulk density}

A comparison of the tillage and forest sites revealed that their soil bulk density had big difference ( $p=$ $0.05)$ at $5-10 \mathrm{~cm}$, but did not exhibit coherent diversity in subsoil (Table 2). Soil water content was obviously higher in the tillage site than in the forest sites. With increased forest restoration age, the soil water content approximately increased. Soil water content in the $\mathrm{C} 84$ site showed no obvious change from 60-95 $\mathrm{cm}$. Water content was lower in $\mathrm{C} 78$ than in C84. With increased depth, the soil water contents in all study sites increased, except for C84.

Table 2. Bulk density and water content of $100 \mathrm{~cm}$ soils from the five study sites.

\begin{tabular}{lccccc}
\hline variables & sites & $\mathbf{5 - 1 0 c m}$ & $\mathbf{3 0 - 3 5} \mathbf{c m}$ & $\mathbf{6 0 - 6 5} \mathbf{c m}$ & $\mathbf{9 0 - 9 5} \mathbf{c m}$ \\
\hline & Tillage & $1.24 \pm 0.16^{\mathrm{b}}$ & $1.23 \pm 0.11^{\mathrm{b}}$ & $1.22 \pm 0.20^{\mathrm{b}}$ & $1.36 \pm 0.10^{\mathrm{a}}$ \\
Bulk density & C99 & $1.05 \pm 0.34^{\mathrm{c}}$ & $1.16 \pm 0.20^{\mathrm{c}}$ & $1.23 \pm 0.30^{\mathrm{b}} 0154$ & $1.17 \pm 0.15^{\mathrm{c}} .111$ \\
$\left(\mathrm{~g} \mathrm{~cm}^{-3}\right)$ & $\mathrm{C} 84$ & $1.43 \pm 0.29^{\mathrm{a}}$ & $1.44 \pm 0.15^{\mathrm{a}}$ & $1.29 \pm 0.21^{\mathrm{ab}}$ & $1.16 \pm 0.20^{\mathrm{c}}$ \\
& $\mathrm{C} 78$ & $1.38 \pm 0.54^{\mathrm{a}}$ & $1.16 \pm 0.25^{\mathrm{c}}$ & $1.34 \pm 0.17^{\mathrm{a}}$ & $1.38 \pm 0.15^{\mathrm{a}}$ \\
& $\mathrm{C} 74$ & $1.38 \pm 0.33^{\mathrm{a}}$ & $1.26 \pm 0.15^{\mathrm{b}}$ & $1.17 \pm 0.20^{\mathrm{c}}$ & $1.27 \pm 0.11^{\mathrm{b}}$ \\
& Tillage & $4.74 \pm 0.11^{\mathrm{a}}$ & $6.98 \pm 0.36^{\mathrm{a}}$ & $7.60 \pm 2.30^{\mathrm{a}}$ & $8.33 \pm 2.01^{\mathrm{a}} 2$ \\
Water content & $\mathrm{C} 99$ & $2.32 \pm 0.27^{\mathrm{b}}$ & $3.36 \pm 0.21^{\mathrm{c}}$ & $4.33 \pm 1.29^{\mathrm{c}}$ & $4.86 \pm 0.56^{\mathrm{c}}$ \\
& $\mathrm{C} 84$ & $2.81 \pm 1.22^{\mathrm{b}}$ & $3.12 \pm 0.36^{\mathrm{cd}}$ & $3.18 \pm 0.64^{\mathrm{d}}$ & $2.98 \pm 1.00^{\mathrm{d}}$ \\
& $\mathrm{C} 78$ & $2.55 \pm 0.75^{\mathrm{b}}$ & $2.90 \pm 1.01^{\mathrm{d}}$ & $3.36 \pm 0.99^{\mathrm{d}}$ & $5.09 \pm 1.53^{\mathrm{bc}}$ \\
& $\mathrm{C} 74$ & $4.07 \pm 0.65^{\mathrm{a}}$ & $4.47 \pm 0.13^{\mathrm{b}}$ & $5.33 \pm 1.64^{\mathrm{b}}$ & $5.68 \pm 2.06^{\mathrm{b}}$ \\
\hline
\end{tabular}

Values are means \pm standard errors of $\mathrm{n}=3$. Significant differences between sites are indicated by superscript letters (LSD; $p \leq 0.05$ ). 


\subsection{Changes in $S O C, A O C$, and DOC}

For the three depths, the change scope of SOC was smaller in the tillage site than in the forest sites
(Table 3). The average SOC of the three depths increased with increased forest age.

Table 3. SOC, AOC and DOC quantity of five study sites.

\begin{tabular}{lcccccc}
\hline Variables & Depths & Tillage & C99 & C84 & C78 & C74 \\
\hline & $20 \mathrm{~cm}$ & $2.23 \pm 0.13^{\mathrm{b}}$ & $2.58 \pm 0.14^{\mathrm{ab}}$ & $3.32 \pm 0.40^{\mathrm{ab}}$ & $3.75 \pm 0.30^{\mathrm{ab}}$ & $6.65 \pm 1.66^{\mathrm{a}}$ \\
$\mathrm{SOC}$ & $40 \mathrm{~cm}$ & $1.73 \pm 0.05^{\mathrm{b}}$ & $1.68 \pm 0.07^{\mathrm{bc}}$ & $1.37 \pm 0.07^{\mathrm{c}}$ & $1.97 \pm 0.03^{\mathrm{b}}$ & $3.31 \pm 0.12^{\mathrm{a}}$ \\
$\left(\mathrm{g} \mathrm{kg}^{-1}\right)$ & $60 \mathrm{~cm}$ & $1.86 \pm 0.04^{\mathrm{b}}$ & $1.38 \pm 0.05^{\mathrm{c}}$ & $1.14 \pm 0.02^{\mathrm{c}}$ & $1.99 \pm 0.12^{\mathrm{b}}$ & $3.05 \pm 0.07^{\mathrm{a}}$ \\
& average & $1.92 \pm 0.03^{\mathrm{b}}$ & $1.81 \pm 0.10^{\mathrm{b}}$ & $1.82 \pm 0.65^{\mathrm{b}}$ & $2.46 \pm 0.56^{\mathrm{ab}}$ & $4.13 \pm 1.03^{\mathrm{a}}$ \\
& $20 \mathrm{~cm}$ & $0.09 \pm 0.01^{\mathrm{a}}$ & $0.19 \pm 0.03^{\mathrm{a}}$ & $0.23 \pm 0.05^{\mathrm{a}}$ & $0.25 \pm 0.02^{\mathrm{a}}$ & $0.49 \pm 0.16^{\mathrm{a}}$ \\
& $40 \mathrm{~cm}$ & $0.04 \pm 0.00^{\mathrm{d}}$ & $0.07 \pm 0.01^{\mathrm{c}}$ & $0.04 \pm 0.00^{\mathrm{cd}}$ & $0.11 \pm 0.01^{\mathrm{b}}$ & $0.17 \pm 0.01^{\mathrm{a}}$ \\
AOC & $60 \mathrm{~cm}$ & $0.03 \pm 0.00^{\mathrm{c}}$ & $0.03 \pm 0.00^{\mathrm{c}}$ & $0.02 \pm 0.01^{\mathrm{c}}$ & $0.06 \pm 0.00^{\mathrm{b}}$ & $0.11 \pm 0.00^{\mathrm{a}}$ \\
$\left.\mathrm{g} \mathrm{kg}^{-1}\right)$ & average & $0.05 \pm 0.00^{\mathrm{b}}$ & $0.09 \pm 0.01^{\mathrm{b}}$ & $0.09 \pm 0.011^{\mathrm{b}}$ & $0.13 \pm 0.01^{\mathrm{ab}}$ & $0.24 \pm 0.02^{\mathrm{a}}$ \\
& $20 \mathrm{~cm}$ & $14.57 \pm 2.32^{\mathrm{bc}}$ & $16.50 \pm 5.36^{\mathrm{b}}$ & $12.80 \pm 6.11^{\mathrm{c}}$ & $20.86 \pm 1.40^{\mathrm{a}}$ & $25.47 \pm 7.56^{\mathrm{a}}$ \\
& $40 \mathrm{~cm}$ & $13.26 \pm 3.26^{\mathrm{c}}$ & $2.76 \pm 0.54^{\mathrm{d}}$ & $12.64 \pm 8.92^{\mathrm{c}}$ & $18.50 \pm 0.20^{\mathrm{b}}$ & $24.40 \pm 2.17^{\mathrm{a}}$ \\
$\left(\mathrm{mg} \mathrm{kg}^{-1}\right)$ & $60 \mathrm{~cm}$ & $16.01 \pm 1.03^{\mathrm{a}}$ & $2.56 \pm 0.85^{\mathrm{b}}$ & $13.82 \pm 0.32^{\mathrm{a}}$ & $16.15 \pm 5.45^{\mathrm{a}}$ & $14.32 \pm 3.16^{\mathrm{a}}$ \\
& average & $14.61 \pm 5.61^{\mathrm{b}}$ & $7.27 \pm 1.23^{\mathrm{c}}$ & $13.09 \pm 5.13^{\mathrm{bc}}$ & $18.50 \pm 6.00^{\mathrm{ab}}$ & $21.40 \pm 4.26^{\mathrm{a}}$ \\
\hline
\end{tabular}

Values are means \pm standard errors, $n=9$ besides average. Averages are calculated with 27 data $(n=27)$ of three depths in each site. Significant differences between sites are indicated by superscript letters (LSD test; $p \leq 0.05$ ).

Compared with tillage, the average SOC values in the 10a and 25a forest sites decreased, increased to the original level (value of the tillage site) in the 31 st year of restoration, and increased continually thereafter. SOC increased with increased age at $20 \mathrm{~cm}$ in the $\mathrm{C} 99, \mathrm{C} 84, \mathrm{C} 78$, and $\mathrm{C} 74$ forest sites. However, SOC decreased at 40 and $60 \mathrm{~cm}$ in C99 and C84. On average, the SOC at three depths and at $20 \mathrm{~cm}$ had more remarkable diversity degrees between the forest and tillage sites. SOC in C74 (35a) was significantly higher than that in the tillage site (distinct diversity degree, $p=0.05$ ) in each depth.

With increased age, $A O C$ increased at $20 \mathrm{~cm}$ in the four forest sites. However, the AOC values at 40 and $60 \mathrm{~cm}$ in $\mathrm{C} 84$ (25 a) were lower than that in the tillage site. LOC in the forest sites obviously increased compared with that in the tillage site. Given the low AOC value at 40 and $60 \mathrm{~cm}, \mathrm{AOC}$ in C84 was lower than that in $\mathrm{C} 99$, but still $84.0 \%$ higher than that in the tillage site. 
The DOC values at 40 and $60 \mathrm{~cm}$ in $\mathrm{C} 99$ were lower, but those at $20 \mathrm{~cm}$ were higher than those in the tillage site. DOC at $20 \mathrm{~cm}$ gradually increased with increased age, except for DOC in C84, which was $3.7 .1 \mathrm{mg} \mathrm{kg}^{-1}$ lower than that in C99. DOC values at 40 and $60 \mathrm{~cm}$ in $\mathrm{C} 99$ were lower than that in the tillage site. From 10 years to 25 years, the DOC values at 40 and $60 \mathrm{~cm}$ increased gradually and approached that of the tillage site after 25 years.

\subsection{SOC proportion}

In all four forest sites, $\mathrm{AOC} / \mathrm{SOC}$ and $\mathrm{ROC} / \mathrm{SOC}$ were higher but LOC/SOC was lower than those of the tillage site (Table 4). The AOC/SOC ratio in C84 (25a) was lower than in $\mathrm{C} 99$ (10a) at the three depths, but showed no obvious difference between $\mathrm{C} 74$ (35a) and C78 (31a). With increased depth, the AOC/SOC ratio decreased gradually. In all four forest sites, AOC/SOC at $60 \mathrm{~cm}$ was $44.9 \%-69.4 \%$ lower than that at $20 \mathrm{~cm}$, compared with the $64.1 \%$ for the tillage site.

Table 4. Contrast of three SOC proportions in five study sites.

\begin{tabular}{lcccccc}
\hline Depths & Variables & Tillage & C99(10a) & C84(25a) & C78(31a) & C74(35a) \\
\hline $20 \mathrm{~cm}$ & AOC $/ S O C$ & $0.04 \pm 0.00^{\mathrm{b}}$ & $0.07 \pm 0.01^{\mathrm{a}}$ & $0.06 \pm 0.01^{\mathrm{a}}$ & $0.07 \pm 0.00^{\mathrm{a}}$ & $0.07 \pm 0.01^{\mathrm{a}}$ \\
& LOC/SOC & $0.68 \pm 0.01^{\mathrm{a}}$ & $0.50 \pm 0.05^{\mathrm{a}}$ & $0.49 \pm 0.05^{\mathrm{a}}$ & $0.64 \pm 0.01^{\mathrm{a}}$ & $0.50 \pm 0.04^{\mathrm{a}}$ \\
& ROC $/ \mathrm{SOC}$ & $0.29 \pm 0.02^{\mathrm{a}}$ & $0.43 \pm 0.05^{\mathrm{a}}$ & $0.45 \pm 0.04^{\mathrm{a}}$ & $0.29 \pm 0.01^{\mathrm{a}}$ & $0.43 \pm 0.03^{\mathrm{a}}$ \\
$40 \mathrm{~cm}$ & AOC $/ \mathrm{SOC}$ & $0.02 \pm 0.00^{\mathrm{b}}$ & $0.04 \pm 0.01^{\mathrm{ab}}$ & $0.03 \pm 0.00^{\mathrm{b}}$ & $0.05 \pm 0.00^{\mathrm{a}}$ & $0.05 \pm 0.00^{\mathrm{a}}$ \\
& LOC/SOC & $0.70 \pm 0.01^{\mathrm{a}}$ & $0.65 \pm 0.03^{\mathrm{ab}}$ & $0.59 \pm 0.03^{\mathrm{ab}}$ & $0.57 \pm 0.03^{\mathrm{b}}$ & $0.606 \pm 0.03^{\mathrm{ab}}$ \\
& ROC $/ S O C$ & $0.28 \pm 0.01^{\mathrm{a}}$ & $0.31 \pm 0.03^{\mathrm{a}}$ & $0.38 \pm 0.03^{\mathrm{a}}$ & $0.38 \pm 0.03^{\mathrm{a}}$ & $0.35 \pm 0.03^{\mathrm{a}}$ \\
& AOC $/ S O C$ & $0.01 \pm 0.00^{\mathrm{c}}$ & $0.02 \pm 0.00^{\mathrm{b}}$ & $0.02 \pm 0.00^{\mathrm{bc}}$ & $0.03 \pm 0.00^{\mathrm{ab}}$ & $0.04 \pm 0.00^{\mathrm{a}}$ \\
& LOC/SOC & $0.74 \pm 0.03^{\mathrm{a}}$ & $0.65 \pm 0.03^{\mathrm{ab}}$ & $0.70 \pm 0.03^{\mathrm{ab}}$ & $0.53 \pm 0.01^{\mathrm{b}}$ & $0.62 \pm 0.02^{\mathrm{b}}$ \\
& ROC/SOC & $0.24 \pm 0.03^{\mathrm{b}}$ & $0.33 \pm 0.03^{\mathrm{ab}}$ & $0.28 \pm 0.03^{\mathrm{b}}$ & $0.44 \pm 0.01^{\mathrm{a}}$ & $0.35 \pm 0.02^{\mathrm{ab}}$ \\
\hline
\end{tabular}

Values are means \pm standard errors, $\mathrm{n}=9$ besides average. Significant differences between sites are indicated by superscript letters (Tukey-Kramer test; $p \leq 0.05$ ).

\subsection{DOC/DON ratio and UV absorption at $280 \mathrm{~nm}$ of $D O M$}

With increased depth, the DOC/DON ratio in all study sites gradually increased (Figure 2). The DOC/DON ratio at $20 \mathrm{~cm}$ of $\mathrm{C} 78$ was close to that of the tillage site, whereas those of the other forest sites decreased to different extents. The lowest value appeared in C84, accounting for $29.9 \%$ of the tillage site. At 40 and $60 \mathrm{~cm}$, the DOC/DON values decreased. At $60 \mathrm{~cm}, \mathrm{DOC} / \mathrm{DON}$ decreased to $36.1 \%-58.3 \%$. 

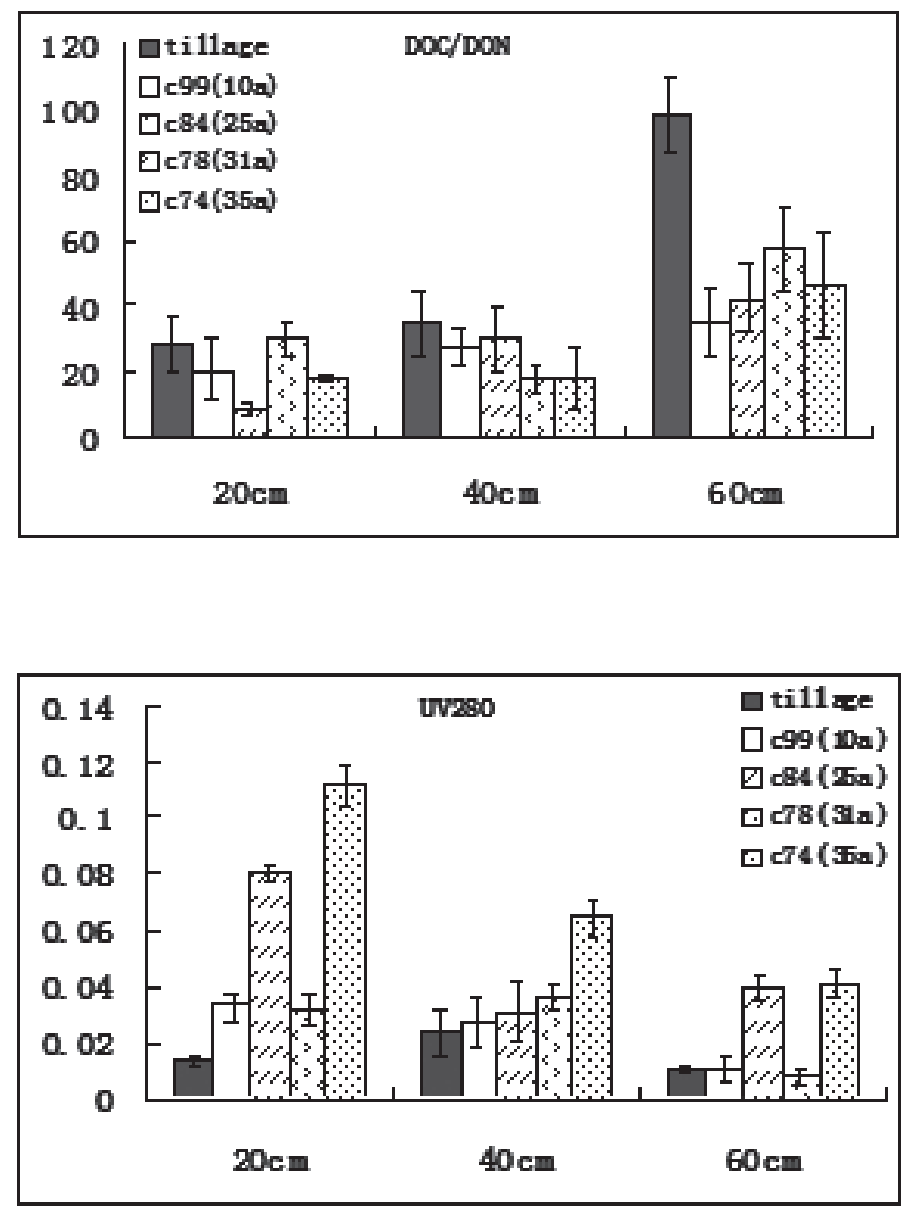

Figure 2. DOC quality changes in soil solution of three depths. Means and standard errors of nine replicates.

UV absorbance decreased with increased depth in each site. At $20 \mathrm{~cm}$, the UV absorbance of $\mathrm{C} 78$ accounts for $39.1 \%$ of that of C84. The UV absorbance index at 20 and $40 \mathrm{~cm}$ was higher in each forest site than that in the tillage site, and increased with increased restoration age. The UV absorbance index at 60 $\mathrm{cm}$ in $\mathrm{C} 99$ and $\mathrm{C} 78$ approached that of the tillage site, but was higher in $\mathrm{C} 84$ and $\mathrm{C} 74$ than in the tillage site.

\section{Discussion}

\subsection{Soil water content}

Soil water content is affected by both vegetation cover on the soil surface and plant roots in subsoil. Soils of forest vegetation in the Loess plateau have lower water content than those in tillage sites because of root 
absorption (Zhao, 2005). Vegetation restoration changes the litter density, root quantity, and ultimately, soil conditions such as $\mathrm{pH}$, temperature, moisture, microorganisms, etc., which are indicated as significant factors affecting soil carbon turnover (Lal, 2005). The results of the evaporation and herbage root absorption at $20 \mathrm{~cm}$, as well as the more powerful arbor root absorption at 40 and $60 \mathrm{~cm}$ show that the water content at three depths did not exhibit the same change trend with increased age. With the development of forest vegetation, the soil water content decreases in subsoil and soil surface, but increases overall. The soil water content changes the conditions of the organic carbon pool and affects its turnover rate, deposited form, and SOC proportion. In semi-arid areas, high soil water contents increase SOC concentration with high humification rates. Hence, the depth distribution of water content can at least partly affect the SOC proportion and concentration.

\subsection{SOC concentration and proportion changes during 35 years forest restoration}

Litters are the most important sources of SOC in the forest ecosystem (Huang et al., 2011). However, the carbon input on surface soil is higher than in deeper soil layers. When tillage was converted into forest, litters accumulated gradually on the soil surface and the depth distribution of SOC was enhanced. Compared with tillage, the depth distribution of SOC in the $10 \mathrm{a}$ to $35 \mathrm{a}$ forests acutely increased at $20 \mathrm{~cm}$ due to litter accumulation. Subsoil organic carbon is mainly generated from root exudates, leaches DOC, fragmentation, and particle SOC movement, which produce limited C input. However, subsoil layers in the tillage site can intercept more organic carbon than those in the forest by ploughing and fertilization, which contribute to the decrease in subsoil organic carbon in young forest restoration.
In general, the amount of SOC is greater in forests than in arable soils (Vesterdal et al., 2002). For example, in tropical areas, SOC increases by $29 \%$ when agricultural land is afforested (Axel et al., 2011). However, a land-use change from arable to forest does not always increase the sequestration of soil organic matter (Vesterdal et al., 2002). In our study, although the average SOC in the four forest sites increased gradually, those in the C99 and C84 forest sites were less than that in the in tillage site. SOC at 40 and $60 \mathrm{~cm}$ showed different changes compared with that at 20 $\mathrm{cm}$, suggesting the diversity of SOC turnover mechanisms between the soil surface and subsoil. Fontaine et al. (2007) found that adding fresh SOC can accelerate old SOC decomposition. After forest restoration, SOC in subsoil was changed by some factors, such as litter fragmentation, SOC composition, and root density, different from that on the surface soil, indicating an asynchronous state. In the 25a forest site, soil water content, SOC, and AOC congruously displayed lower values at 40 and $60 \mathrm{~cm}$. During forest restoration, SOC in subsoil initially increased due to litter fragmentation, which led to a slight increase in the 10a site, and then decreased due to old SOC decomposition and root absorption. Our study proved that the fluctuation of SOC was represented only in the first 25 years of forest restoration. The mechanism of the "decrease factor" such as old SOC decomposition in response to the "increase factor" such as litter fragmentation still needs to be explored.

By the nitrogen fixation function of $R$. pseudoacacia, litters on the soil surface with lower $\mathrm{C} / \mathrm{N}$ ratios led to fast decomposition times, accounting for high AOC quantity (MA et al., 2007). In all four forest sites, the $\mathrm{AOC} / \mathrm{SOC}$ and ROC/SOC ratios were higher than those in the tillage site. This finding suggested that after forest restoration from tillage, AOC ratio and ROC ratio increased, and LOC ratio was consumed. Hence, forest vegetation may help restore carbon in soil. An 
asynchronous state was also suggested by the SOC proportions. In our study, AOC was regarded had the highest biochemical quality within the shortest residence time, and played an important role in plant nutrition. ROC is an inert compound with stable physical and chemical qualities. LOC can be deemed as a recalcitrant compound with the longest residence time (Paul et al., 1999). Kazumi (2011) found that young, fast-MRT soil carbon is decomposed in the upper A horizon, and old, stable soil carbon is decomposed in the lower A horizon in the forest. In the present study, the AOC/SOC ratio in all four forest sites decreased gradually with increased depth. The SOC dynamics and compositions differed between the soil surface and subsoil, leading to different changes during forest restoration.

\subsection{DOC changes in forest sites}

DOC in soil solution is generated from litter leachates, root exudates, and microbial degradation products (Zsolnay, 1996). In the forest ecosystem, litters on the forest floor gradually accumulates, microbial degradation products increase due to high AOC values with short residence times, and root density in subsoil increase. Consequently, the average DOC increases with increased age.

The DOC values at 40 and $60 \mathrm{~cm}$ in $10 \mathrm{a}$ forest were lower than in the other study sites, contributing to lower average DOC values in 10a forest than in the tillage site. Theoretically, both DOC leaching from soil surface and root exudates can lead to the low depth distribution of the study sites, except the 10a forest site. In other words, they decrease the DOC difference between the soil surface and subsoil layer. As important sources, the degradation products of litters and AOC on the soil surface hardly leach through the subsoil layer (Matthias, 2009), especially when AOC on the soil surface is low in the beginning of forest restoration. For young forests, the plant root density and microbe quan- tity have low values, low root exudates, and microbial degradation, leading to low DOC values in the subsoil layer in the 10 a site, although the AOC value was higher than that in the 25 a forest site. With increased root density and microbe quantity, subsoil SOC and AOC in $25 \mathrm{a}$ forest had the lowest values, whereas DOC increased compared with 10 a forest.

UV absorbance and DOC: DON were utilized to evaluate DOM property and composition (Traina et al., 1990). The specific UV absorbance at $280 \mathrm{~nm}$ was considered as a measure of aromaticity (Chin et al., 1994), and DOC:DON was considered as a proxy for the quality of the DOM. Increased DOC:DON indicates reduced bioavailability (e.g., Brian et al., 2009). In our study, DOC:DON at $20 \mathrm{~cm}$ in the forest sites showed no obvious difference with those in the tillage site; however, those at $60 \mathrm{~cm}$ were higher than those in the tillage site. Stephan (2011) found the throughfall contribution to the overall element fluxes was higher for DON than for DOC. Lower DOC/DON values in forest than in tillage sites reflects that after forest restoration, soil solution movement is more active, and/or more recalcitrant DOM is removed from the solution (Brian et al., 2009). On the other hand, forest restoration leads to changes in SOC proportions, such as increased AOC and ROC ratio, as well as decreased LOC, suggesting biodegradation action. A part of DOC is released from SOC biodegradation. DOC in forest sites mainly consist of litter-derived DOC and SOC-derived DOC, providing lower DOC/ DON values and higher acromaticity compositions than in tillage sites.

\section{Conclusions}

When tillage was reverted into forest, SOC exhibited a total, nonlinear, absolute increase, suggesting asynchronous changes. During $R$. pseudoacaci forest restoration, the difference between the soil surface and 
subsoil led to the depth distribution of SOC and AOC. The 25a forest represented a special phase wherein soil water content, SOC, and AOC exhibited low values in the subsoil layer. Apparently, there was a natural C-input course during forest restoration.

After forest restoration, the total SOC and AOC increased and ROC increased, suggesting an internal conversion process among the SOC proportions. In forest ecosystems, the LOC concentration decreases and the degradation and transformation among AOC, LOC, and ROC changed. However, whether the changes benefit the soil carbon input in the long run is still unclear.

In the beginning of forest restoration, DOC concentration at 40 and $60 \mathrm{~cm}$ sharply decreased, suggesting obvious depth distribution. However, the depth distribution of DOC for mature forests was not obvious. DOC does not perfectly indicate the same changes as those of SOC proportions, and more factors control the DOC concentration.

\section{Acknowledgments}

We thank Jinyi Wang from Northwest A\&F University for academic support, who improved the presentation of the manuscript. This work was supported by Knowledge Innovation Project of The Chinese Academy of Sciences $\square$ KZCX2-XB2-05-01 $\square$

\section{References}

Axel, D., Jens, S., Annette, F. 2011. Impact of tropical land-use change on soil organic carbon stocks- a meta-analysis. Global Change Biology. 17, 1658-670.

Brian, D.S., Robert, B. H., Thomas, A.T., et al. 2009. Changes in dissolved organic matter with depth suggest the potential for postharvest organic matter retention to increase subsurface soil carbon pools. Forest Ecology and Management. 258, 2347-352

Bush, J.K. 2008. Soil nitrogen and carbon after twenty years of riparian forest development. Soil Science Society of America Journal. 72, 815-822.

Chin, Y. P., Alken, G., OLoughlin, E. 1994. Molecular weight, polydispersity, and spectroscopic properties of aquatic humic substances. Environmental Science and Technology. 28, 1853-1858.

Collins, H.P., Elliott, E.T., Pustian, K. et al. 2000. Soil carbon pools and fluxes in long-term corn belt agroecosystems. Soil Biology and Biochemistry. 32, 157-168.

Conteh, A., Lefroy, R.D.B., Blair, G.J. 1997. Dynamics of organic matter in soils as determined by variations in ${ }^{13} \mathrm{C} /{ }^{12} \mathrm{C}$ isotopic ratios and fractionation by ease of oxidation. Australian Journal of Soil Research. 35, 881-890.

Fontaine, S., Barot, S., Barre, P., Bdioui, N., Mary, B., Rumpel, C. 2007. Stability of organic carbon in deep soil layers controlled by fresh carbon supply. Nature. 450, 277-280.

Fu, X.L., Shao, M.A., Wei, X.R. et al. 2010. Soil organic carbon and total nitrogen as affected by vegetation types in Northern Loess Plateau of China. Geoderma. 155, 31-35.

Guo, L.B., Gifford, R.M., 2002. Soil carbon stocks and land use change: a meta analysis. Glob. Change Biol. 8, 345-360.

Huang, Y.H., Li, Y.L., Xiao, Y. et al. 2011. Controls of litter quality on the carbon sink in soils through partitioning the products of decomposing litter in a forest succession series in South China. Forest ecology and management. 261, 1170-1177.

Kalbitz, K., Kaiser, K. 2008. Contribution of dissolved organic matter to carbon storage in forest mineral soils. Journal of Plant Nutrition and Soil Science. 171, 52-60. 
Kazumi, K., Yosuke, M., Kenji, T. et al. 2011. A study of the carbon dynamics of Japanese grassland and forest using 14C and 13C Nuclear Instruments and Methods in Physics Research. B. 268, 1106-1109

Kiser, L.C., Kelly, J.M., Mays, P.A. 2009. Changes in forest soil carbon and nitrogen after a thirty-year interval. Soil Science Society of America Journal. 73, 647-653.

Lal, R. 2004. Soil carbon sequestration impacts on global climate change and food security. Science. 304, 1623-1627.

Lal, R. 2005. Forest soils and carbon sequestration. Forest ecology and managemen.t 220, 242-258.

Ma, Y.H., Guo, S.L., Yang, Y.L. et al. 2007. Influence of Vegetation Types on Soil Organic C at Yangou Catchment in the Loess Hilly-gully Region Journal of natural resources (in Chinese) 22(1), 97-106

Michalzik, B., Kalbitz, K., Park, J.H., Solinger, S., Matzner, E. 2001. Fluxes and concentrations of dissolved organic carbon and nitrogen-a synthesis for temperate forests. Biogeochemistry. 52, 173-205.

Post, W.M., Kwon, K.C. 2000. Soil carbon sequestration and land-use change: processes and potential. Glob. Change Biol. 6, 317-327.

Parton, W.J., Sandford Jr, R.L., Sanchez, P.A., Stewart, J.W.B. 1989. Modeling soil organicmatter dynamics in tropical soils. Soil Science Society of America Journal. 39, 153-171.

Paul, E.A.D., Harris, H.P., Collins, U.S., Robertson, G.P. 1999. Evolution of CO2 and soil carbon dynamics in biologically managed, rowcrop agroecosystems. Applied Soil Ecology. 11, 53-65.
Traina, S.J., Novak, J., Smeck, N.E. 1990. An ultraviolet absorbance method of estimation the percent aromatic carbon content of humic acids. Journal of Environmental Quality. 19, 151-153.

Vesterdal, L., Ritter, E., Gundersen, P. 2002. Change in soil organic carbon following afforestation of former arable land. Forest Ecology Management. $169,137-147$.

Wang, Y.F., Fu, B.J., Lü, Y.H., Song, C.J., Luan, Y. 2010. Local-scale spatial variability of soil organic carbon and its stock in the hilly area of the Loess Plateau, China. Quatern Res. 73, 70-76.

Wang, Y.F., Fu, B.J., lv, Y.H. et al. 2011. Effects of vegetation restoration on soil organic carbon sequestration at multiple scales in semi-arid Loess Plateau, China. Catena. 85, 58-66.

Zhao, J.B., Du, J., Zhou, Q. et al. 2005. Dry layer of soil below artificial forest near XianYang in Shaanxi. Scientia geographica sinica. 25(3), 322329. (in Chinese)

Zhou, G.Y., Zhou, C.Y., Liu, S.G. et al. 2006. Belowground carbon balance and carbon accumulation rate in the successional series of monsoon evergreen broad-leaved forest. Science in China Series D: Earth Sciences. 49, 311-321.

Zsolnay, A. 1996. Dissolved humus in soil waters. In: Piccola. A. (Ed.). Humic Substances in Terrestrial Ecosystems. Elsevier. Amsterdam pp, 171-223.

Zsolnay, A., Baigar, E., Jimenez, M. et al. 1999. Differentiatingwith fluorescence spectroscopy the sources of dissolved organic matter in soils subjected to drying. Chemosphere. $8,45-50$ 